Bol. Acad. peru. leng. 53. 2012 (137-143)

\title{
EUGENIO CHANG EN LA TRADICIÓN DE LOS DIARIOS
}

\author{
Marco Martos Carrera
}

Academia Peruana de la Lengua

Fecha de recepción: $\quad$ 26/04/2012

Fecha de aceptación: $\quad$ 05/06/2012

\section{Introito}

William Somerset Maugham publicó en 1949 quince gruesos volúmenes con una gran cantidad de recuerdos, notas y experiencias bajo el título de Carnet de un escritor, textos de particular interés para los lectores familiarizados con sus novelas y cuentos, pero considerablemente menos atractivos para quienes abren esas páginas para conocer a un autor por primera vez. Pero el secreto encanto de estos apuntes es que el lector ve desfilar una gama de personajes que el autor conoció en sus viajes, toma conocimiento también de numerosos episodios vividos por el propio novelista o que le fueron referidos, para después aparecer en su obra imaginativa transformados en materia literaria. Maugham quería retener y fijar de un modo breve y conciso observaciones y datos que le parecían significativos para su propia filosofía de vida. 
Esas páginas empezaron a escribirse en 1892, cuando el autor era estudiante de medicina y son, ciertamente, un batiburrillo, una trastienda donde el lector puede trabucar todo para encontrar algunas gemas, circones o piedras de fantasía. Maugham cuenta cómo dentro de su práctica médica se le fue infiltrado el virus de la literatura como una curiosidad acuciante que lo acicatea y lo lleva a viajar; así traba conocimiento de personajes pintorescos o célebres. En la medida que envejece, Maugham aumenta su ardiente curiosidad por la vida de los hombres y va trazando, finalmente, el perfil del propio autor, como le habría gustado a Borges.

Han pasado cerca de sesenta años después de la publicación del Carnet de Somerset Maugham y pocos se aventuran hoy en sus páginas, que tal vez parezcan excesivas para las premuras de los lectores del siglo XXI, pero si imaginásemos, por un momento, que nos topamos con esos volúmenes en una convalecencia o en una prisión, recuperaría su fulgor inicial, el atractivo que tiene todo buen escritor, esa delicia que guarda siempre una obra bien escrita. El escritor católico Charles Du Bois (1882-1939) publicó algunos fragmentos de su Diario correspondiente a los años 1908-1928. Cuando murió, su viuda encontró numerosas páginas que, como en el caso de Somerset Maugham, necesitaron varios volúmenes. Las páginas de Du Bois muestran su cocina literaria, sus planes de trabajo, sus proyectos de libros o artículos, los consejos que se ofrece a sí mismo y las conversaciones con muchos de sus amigos, entre los que estaban Gide, Bergson, Valéry. Percibimos el conocimiento que tuvo de la literatura francesa e inglesa, los matices de sus meditadas opiniones. Pero lo que aleja a estas páginas de lo que podemos llamar un ensayo es que, a contrapartida de un libro limpiamente literario, sentimos la presencia de la vida personal del autor con toda sus asperezas, los trabajos de Hércules que tuvo que pasar Du Bois para sobrevivir día a día, indiferente a las exigencias del público y a las propias premuras de los editores. Du Bois, que aspiraba con certeza al cielo como lo pinta la Biblia, merece salir del infierno al que lo han condenado las modas literarias de hogaño.

En 1939, André Gide (1899-1951) recogió con el título de Journal sus diarios íntimos, que empiezan en 1889. La fama de la que 
gozó el autor a partir de la obtención del Premio Nobel, ahora perdida casi totalmente, sin excepción posible, hacía interesante para el público todo lo que escribía. Las páginas juveniles del autor constituyen lo que podríamos llamar una investigación sobre el propio yo. Pero a partir de 1894, las notas se hacen más breves y, justo es decirlo, más interesantes. El diario deja de ser una confesión íntima para transformarse en un conjunto de máximas y reflexiones morales o de opiniones sobre autores que aún hoy día resultan interesantes, como estas sobre Bourget: «Este arte utilitario no vive más que un momento y, apenas cesa de ser útil, no despierta más interés que el de una curiosidad histórica. El mismo aspecto serio de su obra hace sonreír, y la ausencia de ironía sobre sí mismo invita bien pronto a la ironía del lector. Nada más caduco que las obras serias. Ni Molière ni Cervantes ni aun Pascal son serios: son graves».

Uno de los episodios más interesantes de las anotaciones personales de Gide es el Cabier vert de 1916-17, que testimonia una crisis espiritual que lo llevó a acercarse al catolicismo. Son palabras llenas de angustia, de búsqueda incesante, de apetencia de Dios. En este periodo, Gide considera a Cristo como bálsamo del alma atormentada. Sin embargo, esta experiencia es un momento en la vida del autor. Prevaleció en su espíritu inquieto y aventurero el deseo de vincularse a acontecimientos del mundo intelectual y político. Las páginas que público en 1934, absolutamente sinceras, sorprendieron por su adhesión a la Unión Soviética, pero solo dos años más tarde, en 1936, Gide retornó a su antigua individualidad y a su libertad de espíritu inconforme con cualquier doctrina política. Algo de lo mejor de Gide son las páginas confesionales de Si la semilla no muere.

De índole totalmente diversa son los Diarios de los hermanos Goncourt, Edmond (1822-1896) y Jules (1830-1870). Nueve volúmenes que contienen las anotaciones hechas día a día, de hechos o escenas vistas, o de observaciones propias o de amigos. En estos apuntes aparecen Flaubert, Taine, Gautier, Sainte- Beuve, Matilde Bonaparte. Hay páginas memorables como las anotaciones sobre una fiel doméstica que simultáneamente era una ramera y que llevaba con donosura su doble vida. Los Goncourt se muestran como finos observadores de la realidad, como 
personas dotadas de una conmiseración profunda por el sufrimiento. Despojados del preciosismo del que hacen gala en sus novelas y en otros escritos, los Goncourt no solamente expresan con galanura su alma de artistas, sino pintan un fresco de la sociedad francesa del siglo XIX, que mantiene su interés a pesar de paso del tiempo.

Se ha querido en estos párrafos dar alguna noticia, espigar en el mundo de los diarios, como un introito para referirnos a Reminiscencias de Europa y África de Eugenio Chang Rodríguez, pero los diarios son un mundo aparte, casi otra nación, un género que se diferencia mucho de la ficción y del ensayo. Quien se entusiasme tiene mucha tela para cortar: El Diario de María Bashkirseff, esa muchacha rusa amiga de escritores y artistas que vivió en el siglo XIX y que paseó su existencia de niña rica por Baden-Baden, Niza, Roma, Napoles, Florencia, París. Está también el Diario de Johann Gottfried Herder (1744-1803), el famoso Diario de Samuel Pepys (1632-1703), escrito en una taquigrafía especial en que, junto al inglés, se mezclan el español, francés, italiano y latín, documento de extraordinario interés para conocer la vida diaria y la política inglesa del siglo XVII. Y así, hay tantos diarios, como el magnífico de Charles Ferdinand Ramuz, escritor suizo (1878-1947) o el Diario de Stendhal (1783-1842), uno de los más conocidos y comentados. Dostoievski publicó Diario de un escritor durante los años 1843-76, una colección de artículos sobre todos los problemas cotidianos, en los que el autor expone sus ideas políticas, sociales y religiosas. Lo que le interesa más es la cuestión eslava, tanto que llega a escribir: «Rusia es superior a Europa, y a ella le corresponde la hegemonía de la civilización europea». Pero aquí se nos convoca para escribir sobre Eugenio Chang, y eso es lo que se hace justamente a partir de esta línea.

\section{Eugenio Chang o la voluntad de escribir}

Quienes vivimos en el Perú tenemos una imagen bastante fragmentaria del quehacer intelectual de Eugenio Chang. En él aparecen con nitidez todas las imágenes del exiliado. Del intelectual exiliado diríamos mejor. Y para ser más preciso, del intelectual exiliado, nacido 
en el Perú, en el extremo de occidente, como diría el poeta Rodoldo Hinostroza, que tiene en su magín toda la tradición que nos viene de Grecia, se enriquece con el Renacimiento y encuentra su originalidad más prístina en la mezcla en partes iguales entre aquello que viene de Homero y lo que nos ofrece como diferente el Inca Garcilaso de la Vega y la tradición china que conoció desde su infancia. Vinculado desde joven al partido aprista, Chang mantiene en su escritura los intereses del Apra auroral: la preocupación por el estudio del anarquismo y la figura paradigmática de González Prada, el interés por Haya de la Torre, Manuel Seoane y Antenor Orrego. En otro terreno, como puede verse por su vasta bibliografía, Eugenio Chang es un lingüista, de los más reputados en ese mundo de especialistas. Pero es sobre todo, alguien que encuentra en la escritura la manera de vivir. Quienes lo conocemos solo imaginamos a Eugenio Chang o escribiendo o conversando.

El libro que tenemos entre manos es de naturaleza extraña. Y todo lo extraño llama la atención. Se dice esto porque es de difícil clasificación, aunque lo más cercano parece ser la tradición de los diarios. Solo que este texto se diferencia bastante de los diarios conocidos, sin ser absolutamente diferente a ellos. Un diario, por definición, nos ofrece puntos de vista individuales sobre hechos asuntos o temas. Un buen ejemplo entre los peruanos son las llamadas Prosas apátridas de Julio Ramón Ribeyro. Editadas cinco veces entre 1975 y 1992, han logrado un lugar de privilegio entre sus páginas preferidas por los lectores y se han convertido en objetos de lujo pues son casi inhallables en las librerías de primera mano. La primera edición tenía una introducción de José Miguel Oviedo y las últimas son precedidas de palabras del mismo Ribeyro que datan de 1992. Esas señas que proporciona el autor son revelaciones escasas de lo que ocurre detrás de las mamparas literarias. Citando a Tagore en la página liminar que precede a todo el libro, Ribeyro escribe: «El botín de los años inútiles, que con tanto celo guardaste, disípalo ahora: te quedará el triunfo desesperado de haber perdido todo». Luego explica que el sentido de apátrida no es de alguien que sin serlo se considera como tal, sino que se trata de textos que no habían encontrado sitio en sus libros ya publicados y que erraban entre sus papeles sin destino ni función 
precisos. Se trata, pues, de textos que según su autor, carecen de un territorio literario propio. Al reunirlos en un volumen, el escritor dice haber querido salvarlos de un aislamiento, dotarlos de un espacio común y permitirles existir gracias a la contigüidad y al número. Al tomar esa decisión Ribeyro confiesa haber tenido presente El spleen de París de Charles Baudelaire, no por emulación presuntuosa, sino por el carácter "disparate" del conjunto y por tratarse de un libro que, como dice el poeta, es a la vez cabeza y cola, alternativa y recíprocamente. Y que puede leerse en consecuencia por el comienzo, por el medio o por fin. La confidencia termina aseverando que la mayor parte de los textos ha sido escrita en París y, como en la obra del autor de Las flores del mal, esta ciudad figura nominalmente como telón de fondo en muchos de estos fragmentos.

De parecida manera a Ribeyro, en este libro de Chang, aparece el material escrito que no tiene sitio en libros orgánicos. El texto, a pesar del orden con que se presenta, tiene un carácter miscelánico y por lo tanto puede leerse empezando por cualquiera de sus apartados. Da noticia de una serie de eventos lingüísticos, por ejemplo, y, en su parte central, ofrece información personal sobre los viajes del autor, junto con su esposa Raquel Chang. La circunstancia de un encuentro literario en alguna ciudad europea o africana es motivo suficiente para estimular de manera insólita a la pluma de Chang. Un ejemplo, de los muchos que el libro ofrece, es un congreso en la ciudad alemana de Eichstätt, en 2001. El texto se detiene sobre la historia del pueblo. Nos enteramos de que el nombre tiene un origen celta, y que fueron celtas los que ocuparon el territorio durante el milenio anterior al nacimiento de Cristo. Nos informa Chang que del año 80 al 280 de la era cristina formó parte de una provincia norteña romana y que a partir de 1305 pasó a ser propiedad del arzobispado. Eistätt fue integrado a Baviera a partir de 1802 y ahora, merced al esfuerzo de Karol Kohut, un peruanista alemán de origen checo, es un lugar donde se estudia la cultura de nuestro país. Nos enteramos de estas pinceladas históricas, pero también Chang nos informa de detalles sorprendentes, como el que después de una agotadora sesión académica, los profesores adustos, 


\section{https://doi.org/10.46744/bapl.201201.007}

se transforman en delicados bailarines por dos horas. Ese contraste es el que hace interesante al libro.

Como la vida misma, el texto de Chang mezcla lo sólito con lo insólito, sus propios textos y comentarios de críticos. Puede decirse con propiedad que en este libro se encuentra, como dice la tradición popular, "de todo como en botica".

\section{Correspondencia:}

\section{Marco Martos Carrera}

Presidente de la Academia Peruana de la Lengua.

Correo electrónico: marco.martos@academiaperuanadelalengua.org 